\title{
On the genus Latonigena Simon (Araneae, Gnaphosidae): description of two new species, the female of $L$. santana, and new records
}

\author{
Nicolás LÓPEZ CARRIÓN \& Cristian J. GRISMADO
}

\begin{abstract}
División Aracnología, Museo Argentino de Ciencias Naturales "Bernardino Rivadavia”, Av. Angel Gallardo 470, C1405DJR, Buenos Aires, Argentina.carrion.nico@gmail.com; grismado@macn.gov.ar
\end{abstract}

\begin{abstract}
The taxonomy of the genus Latonigena Simon is updated after the study of the collection of the Museo Argentino de Ciencias Naturales (Buenos Aires). Two new species are described: L. pampa, n. sp., from Buenos Aires Province, Argentina, and L. pittieri, n. sp., from Aragua, Venezuela (the first record of a member of this genus from that country). Three species previously known from Brazil (L. turvo, L. lami, and L. santana) are newly reported from Argentina, and the female of the latter is here described for the first time. Zelotes zonatus (Holmberg) is considered nomen dubium.
\end{abstract}

Key words: Ground spiders, taxonomy, Argentina, Venezuela.

Resumen: Acerca del género Latonigena Simon (Araneae, Gnaphosidae): descripción de dos nuevas especies, la hembra de L. santana, y nuevos registros. Se actualiza la taxonomía del género Latonigena Simon, después del estudio de la colección del Museo Argentino de Ciencias Naturales (Buenos Aires). Se describen dos nuevas especies: L. pampa, n. sp., de la provincia de Buenos Aires, Argentina, y L. pittieri, n. sp., de Aragua, Venezuela (el primer registro del género para ese país). Tres especies previamente conocidas de Brasil ( $L$. turvo, L. lami y L. santana) se reportan por primera vez para Argentina, y la hembra de esta última se describe aquí por primera vez. Zelotes zonatus (Holmberg) es considerado nomen dubium.

Palabras clave: Arañas del suelo, taxonomía, Argentina, Venezuela.

\section{INTRODUCTION}

The South American gnaphosid genus Latonigena Simon comprises to date eight species, and is distributed in Brazil, Bolivia, Argentina and Uruguay (Platnick, 2013). The genus remained little known for more than a century since its description, until recently Jorge et al. (2013) studied the taxonomy, distribution and biology of the type species (L. auricomis Simon), and Ott et al. (2012) described seven species from Brazil and Bolivia, and transferred L. africana Tucker to the genus Trichothyse Tucker.

This genus comprises medium-sized spiders with a conspicuous abdominal pattern (with transversal alternated dark and light bands), a dorsal scutum on the male abdomen, and lacking preening combs, all characters that Murphy (2007) used to locate it in the Herpyllus group.

Besides the above mentioned species, there is an additional described species that could conceivably fit in the genus: Zelotes zonatus (Holmberg, 1876), described originally in the genus Pythonissa. The type material of this species (as occurred with all other species described by Holmberg) no longer exist, but the original description and illustrations strongly suggest that it could belong to Latonigena (Holmberg, 1876:10), as well as the suggestive data: "Viven con preferencia bajo la corteza de Eucalyptus..." (they live with preference under bark of Eucalyptus), suggest that this might be a senior synonym of $L$. auricomis, also common under Eucalyptus bark in the same locality (Buenos Aires). However, as it is shown below, Latonigena lami is also present in Buenos Aires, making impossible to discern to which of the two species known in the area could belong the specimens reported by Holmberg. Given that the name Zelotes zonatus cannot be certainly assigned to either species, we consider it here as nomen dubium.

The study of the collection of the Museo 
Argentino de Ciencias Naturales (Buenos Aires) led us to update the knowledge on the genus, proposing two new species ( $L$. pampa from Argentina, and L. pittieri, from Venezuela), and expand to central Argentina the distribution of three species previously known only from Brazil, $L$. lami, $L$. turvo, and $L$. santana, with the description of the female of the latter species.

\section{MATERIAL AND METHODS}

Specimens are deposited in the Arachnological Collection of the Museo Argentino de Ciencias Naturales "Bernardino Rivadavia", Buenos Aires, Argentina (MACN-Ar, Cristina L. Scioscia). Drawings were made using a camera lucida mounted on a Leitz stereoscopic microscope or an Olympus BH-2 compound microscope. The internal genitalia were cleared in clove oil. Photographs of the preserved specimens were taken with a Leica DFC 290 digital camera mounted on a Leica M165 C stereoscopic microscope, and the focal planes were composed with Helicon Focus 4.62.2. All measurements are in millimeters. Abbreviations and terminology follow, where possible, Ott et al. (2012); macrosetae notation follows Grismado (2008), only surfaces bearing spines listed.

\section{SYSTEMATICS}

\section{Family GNAPHOSIDAE Pocock, 1898} Genus Latonigena Simon, 1893

\section{Latonigena pampa, $\mathrm{n}$. $\mathrm{sp}$.}

(Figs. 1; 2a, d, g; 3a-c; 4b)

Type material. Male holotype from Argentina, Buenos Aires, Reserva Ecológica Otamendi, 10.VI.1997, M. Ramirez, C. Grismado, L. Compagnucci and F. Uehara coll. (MACN-Ar 30555). Paratypes: same data as the holotype: one female (MACN-Ar 30835) and one male (MACNAr 18297, preparation CJG 1458, together a immature); Rio Luján, 05-X-1993, M. Ramírez and A. Pérez coll. (MACN-Ar 18284).

Etymology. The specific epithet is a noun in apposition, and refers to the Pampa, the eco-region where the type locality belongs.

Diagnosis. Males of Latonigena pampa can be distinguished by their relatively elongated copulatory bulb, with a long embolus originating basally in the tegulum, accompanied dorsally by a weakly sclerotized conductor, which is relatively large, with a wide base of insertion, and that surpass the tip of the embolus (Figs. 1d, 3a); the RTA is short, with a slightly sclerotized tip, that points to ventrally (Figs. 1e, 3b). Females resemble to those of $L$. lami and $L$. beni by lacking anterior epigynal hoods and by the general shape of the median epigynal septum, but this structure is relatively longer, with curved margins in the anterior half, that turn straight, parallel, at the posterior half (Fig. 2g); also by its long, sinuous copulatory ducts, with openings anteriorly located (Fig. 3c).

Description. Male (holotype). Coloration (Figs. 1a, b): carapace, sternum, endites and chelicerae brown, leg articles light-brown, patellae lighter, all femora darkened. Abdomen, dorsal dark brown with three transversal whitish bands, one anterior (concealed under the dorsal scutum), one median and other subterminal. Dorsal scutum oval reaching to the posterior margin of the median whitish band (Fig. 1a). Ventrally marbled brown (Fig. 1b). Spinnerets dark brown. Total length 4.60. Carapace 2.00 long, 1.20 wide. Eye diameters and interdistances: AME 0.076, ALE 0.075, PME 0.058, PLE 0.069; AME-AME 0.04, AME-ALE touching, PME-PME 0.073, PMEPLE 0.039, ALE-PLE 0.078. Leg measurements: I - femur 1.30 / patella 0.69 / tibia $0.89 /$ metatarsus 0.71 / tarsus $0.47 /$ total 4.06 ; II -1.20 / $0.66 /$ $0.84 / 0.70 / 0.45 / 3.85$; III - 1.10/ 0.57/ 0.75/ 0.73/ $0.56 / 3.71$; IV - 1.40/ 0.65/ 1.10/ 1.10/ 0.53/ 4.78 . Leg spination: I: Femora D 1-0-1-1; P 0-0-1; PD 0-0-1/ Tibiae P 1; VR 1-1-0-1 ap; VP 0-1-1 ap/ Metatarsi V 2-0. II: Femora D 1-0-1-1; PD 0-0-1; P 0-0-1/ Tibiae P 0-0-1; DP 1; VR 1-1-0-1 ap; VP 0-1-1 ap/ Metatarsi V 2-0 (left 1-2-0). III: Femora D 1-0-1-1; DP 0-0-1-1; DR 0-0-1-1/ Patellae R 1/ Tibiae D 2-0; V 1-2-2 ap; DR 1; DP 1; P 1-1; R 0-0-1/ Metatarsi P 1; V 2-0-1 ap; RD 0-0-1; R 1; RV 0-0-1; PD 0-0-1; PV 0-0-1. IV: Femora D 1-01-1; DP 0-0-1-1; DR 0-0-0-1/ Tibiae P 1; PV 1-1; VR 0-0-1 ap; V 1; VP 1-1-1; R 1; RD 1-0/ Metatarsi P 1-1 ap; R 1-1 ap; RD 1-1-1; PD 0-1-1; V 2-2-2 ap. Palp: ventrally curved retrolateral tibial apophysis with slightly sclerotized tip (Figs. 1e, 3b); bulb elongated; spermatic duct gently curved at distal half; embolus originating basally, conductor weakly sclerotized, relatively large, with a wide base of insertion, surpassing the embolus tip (Figs. 1d, 3a).

Female (MACN-Ar 18284, paratype). Coloration as in male, except by the more contrasted transversal band pattern on the abdomen, the median 

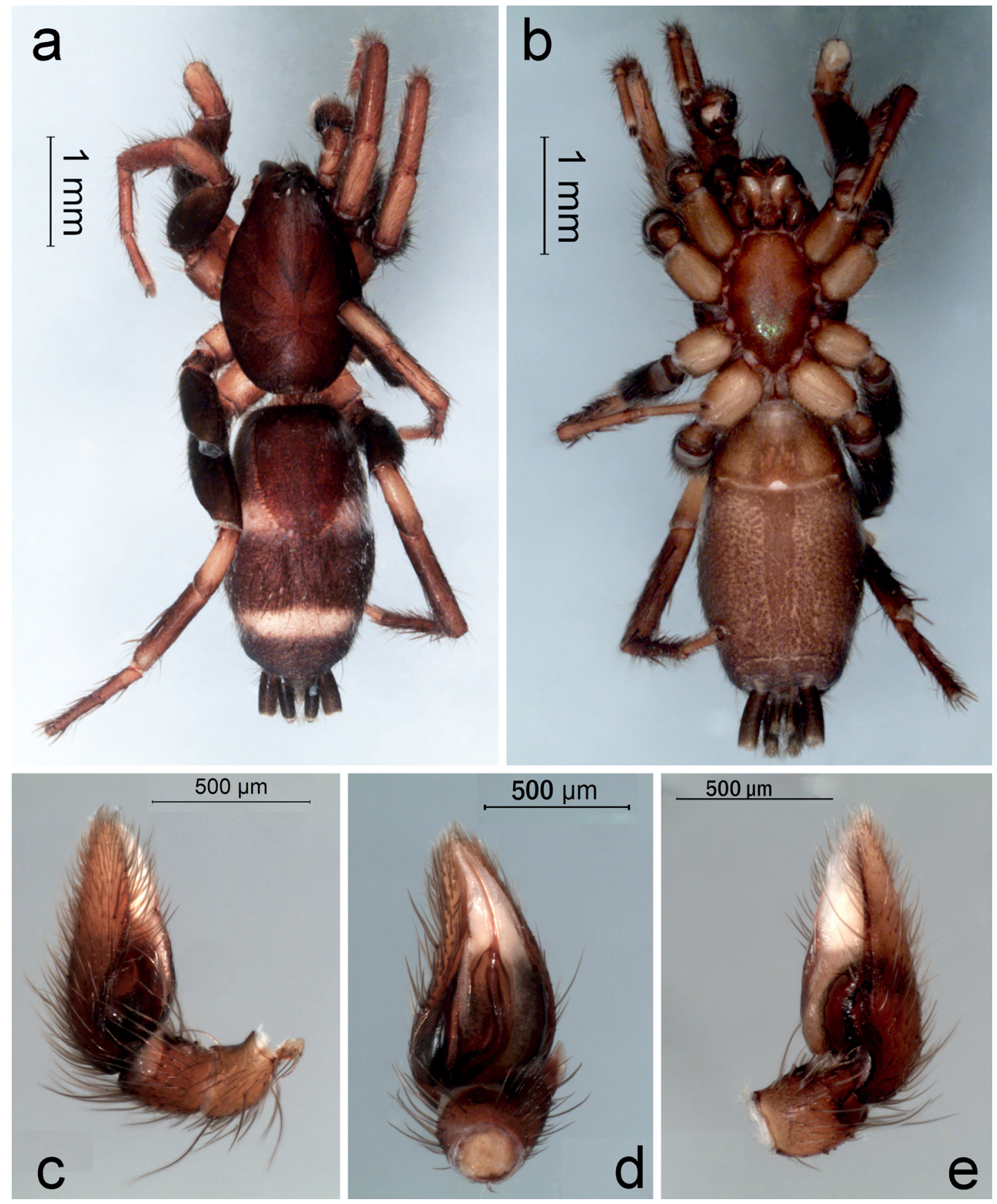

Fig. 1. Latonigena pampa sp. nov., male holotype (MACN-Ar 30555). a habitus dorsal, b same, ventral, $\mathbf{c}-\mathbf{e}$, left palp: c prolateral view, $\mathbf{d}$ ventral view, e retrolateral view.

light band constricted at middle, and by lacking PLE 0.066; AME-AME 0.055, AME-ALE touchthe dorsal scutum (Fig. 2a); ventrally whitish at the median area (Fig. 2d). Total length 7.20. Carapace 3.20 long, 2.10 wide. Eye diameters and interdistances: AME 0.09, ALE 0.11, PME 0.11, ing, PME-PME 0.14, PME-PLE 0.05, ALE-PLE 0.12 . Leg measurements: I - femur $1.60 /$ patella 1.00 / tibia 1.20 / metatarsus 1.00 / tarsus 0.60 / total 5.40; II - 1.60/ 1.00/ 1.10/ 0.90/ 0.61/ 3.71; III 
- 1.50/0.77/ 0.94/ 1.00/ 0.67/4.88; IV - 1.90/ 1.10/ 1.40/ 1.60/ 0.68/ 6.68. Leg spination: I: Femora D 1-0-1-1; P 0-0-1; PD 0-0-1/ Tibiae P 1; VR 1-1-0-1 ap; VP 1-1-2 ap (left 0-1-2 ap)/ Metatarsi V 2-0. II: Femora D 1-0-1-1; PD 0-0-1; P 0-0-1/ Tibiae P 0-0-1; VP 0-1-1 ap; VR 1-1-1 ap/ Metatarsi V 2-0. III: Femora D 1-0-3-3/ Patellae R 1/ Tibiae D 1-0-0; V 1-2-2 ap; R 0-1; P 2-1-1/ Metatarsi P 1-10-1 ap; V 2-0-2 ap; RD 1-1-0-1; R 1 ap; PD 1-1 ap. IV: Femora D 1-1-3/ Tibiae VR 0-1-1 ap; V 1-1-1 ap; VP 1-1; R 1-1/ Metatarsi P 1 ap; R 1-1 ap; D 2-2; PD 1-1-0-0; V 2-2-2 ap. Genitalia: Epigynum septum relatively long, with curved margins in the anterior half, turning straight, nearly parallel posteriorly (Fig. 2g). Copulatory ducts long, sinuous, copulatory openings anteriorly located (Fig. 3c).

Distribution. Known only from Buenos Aires Province, Argentina (Fig. 4b).

Other material examined. None.

Latonigena pittieri, $\mathrm{n}$. sp.

(Figs. 2b, e, h; 3d; 4a)

Type material. Female holotype fom Venezuela, Aragua, Maracay, XI.1968, G. Williner coll. (MACN-Ar 18358).

Etymology. The specific name is a noun in apposition in honor to Henri François Pittier (18571950) a Swiss geographer and botanist who lived in Venezuela and devoted many years studying the flora and fauna in the country. The type locality of this species is very close to the National Park named after this scientist.

Diagnosis. The female of Latonigena pittieri resembles to those of $L$. auricomis by its very narrow median septum (Fig. 2h), but, besides its very small body size, its copulatory ducts are longer, which open in a more advanced position, at the same level of the anterior border of the spermathecae (Fig. 3d).

Description. Female (holotype, in poor condition). Coloration (Figs. 2b, e): carapace, sternum, endites and chelicerae light brown, leg articles light-brown, lighter from patellae to distal. Abdomen, dorsally brown with three transversal whitish bands, one anterior, one median and other subterminal (slightly wider). Ventrally uniformly whitish, darkened at the posterior third and spinnerets (Fig. 2e). Total length 4.70.
Carapace 2.20 long, 1.40 wide. Eye diameters and interdistances: AME 0.08, ALE 0.07, PME 0.09, PLE 0.05; AME-AME 0.04, AME-ALE 0.01, PME-PME 0.09, PME-PLE 0.05, ALE-PLE 0.20. Leg measurements: I - femur 1.20/ patella 0.74/ tibia $0.82 /$ metatarsus $0.64 /$ tarsus absent; II $1.20 / 0.73 / 0.79 / 0.75 /$ tarsus absent; III -1.10 / $0.64 / 0.71 / 0.87 / 0.51 /$ total 3.83 ; IV - 1.30/ 0.75/ 1.00/ 1.20/ 0.48/ 4.73. Leg spination: I: Femora P 0-0-1; D 1-1-2/ Tibiae V 1 ap/ Metatarsi V 1-0. II: Femora P 0-0-1; D 1-1-2/ Tibiae V 1-1 ap/ Metatarsi V 1-0. III: Femora D 1-3-3/ Patellae R 1/ Tibiae P 1-0-1; V 1-2-0-2 ap; R 1-1; D 2-1-0 (in the left leg one of the dorsal spines displaced to retrolateral)/ Metatarsi P 0-1-0-1; V 2-0-2 ap; $\mathrm{R}$ 1-2 ap; D 0-2-0-2. IV: Femora D 1-1-2/ Tibiae V 1-2-0-2 ap; P 1-1; R 1-1/ Metatarsi P 0-1-0-2 ap; R 1-2 ap. Genitalia: median septum narrow, copulatory ducts relatively long, copulatory openings in advanced position, at the same level of the anterior border of the spermathecae (Figs. 2h, 3d).

Distribution. Known only from the type locality, in Northern Venezuela (Fig. 4a).

Other material examined. None.

Latonigena santana Ott, Rodrigues \& Brescovit

(Figs. 2c, f, i; 3e; 4b)

Ott, Rodrigues \& Brescovit 2012:232. Holotype male from Morro Santana, Porto Alegre, Rio Grande do Sul, Brazil, 12.XI.1992, O. Tchorpke coll., deposited in MCTP. Not examined.

Material examined. Argentina: Buenos Aires: Tandil, no date, J. M. Viana coll., 1 male, 1 female and 1 immature (MACN-Ar 195); Las Flores, 24.V.1931, J.B. Daguerre coll., 2 males (MACNAr 18313). Santa Fe: Las Gamas, 27-30.X.1994, M. Ramírez and J. Faivovich, 1 male (MACN-Ar 18253).

Diagnosis. The female of Latonigena santana is similar to those of $L$. colombo in the shape of the median septum, the presence of paired anterior hoods, and the elongated spermathecae, narrowed anteriorly. However, the anterior hoods are more separated (not touching medially, as in L. colombo), the anterior part of the septum is narrower, the posterior part of septum is wider (Fig. 2i) and the spermathecae have a more acute anteriorly (Fig. 3e). For the male, see Ott et al (2012: 232). 

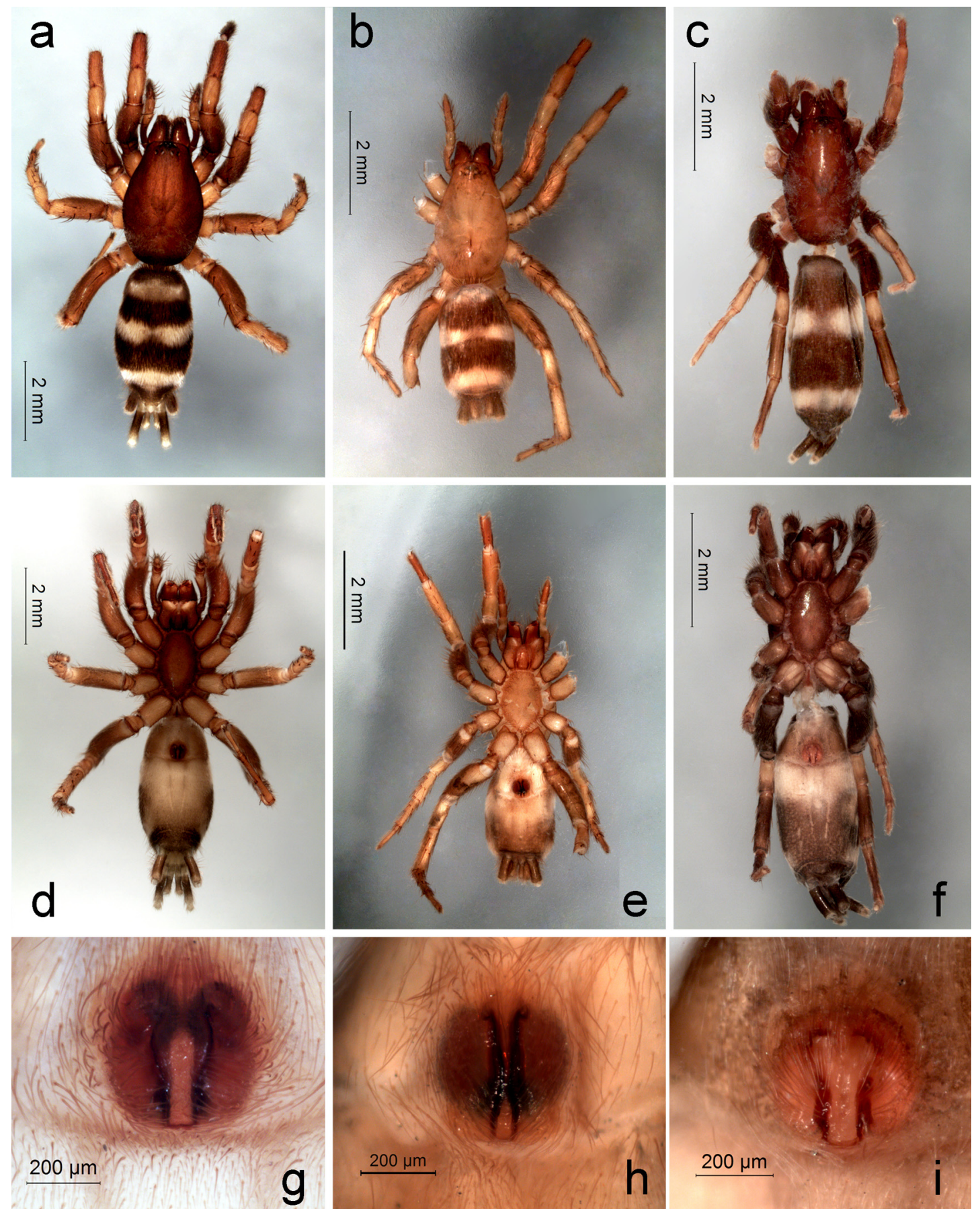

Fig. 2. Latonigena spp. a, d, $\mathbf{g}$ L. pampa, sp. nov., female paratype (MACN-Ar 18284); b, e, $\mathbf{h}$ L. pittieri sp. nov., female holotype; c, f, i L. santana Ott, Rodrigues \& Brescovit, female from Tandil (MACN-Ar 195). a-c habitus dorsal; $\mathbf{d}-\mathbf{f}$ same, ventral; $\mathbf{g}-\mathbf{i}$ epigynum, ventral view.

Description (female MACN-Ar 195): Coloration (Figs. 2c, f): carapace, sternum, endites and chelicerae brown, leg articles light-brown, patellae lighter, all femora darkened, coxae IV lighter than I-III. Abdomen, dorsally brown with three transversal whitish bands, the anterior one inconspicu- 


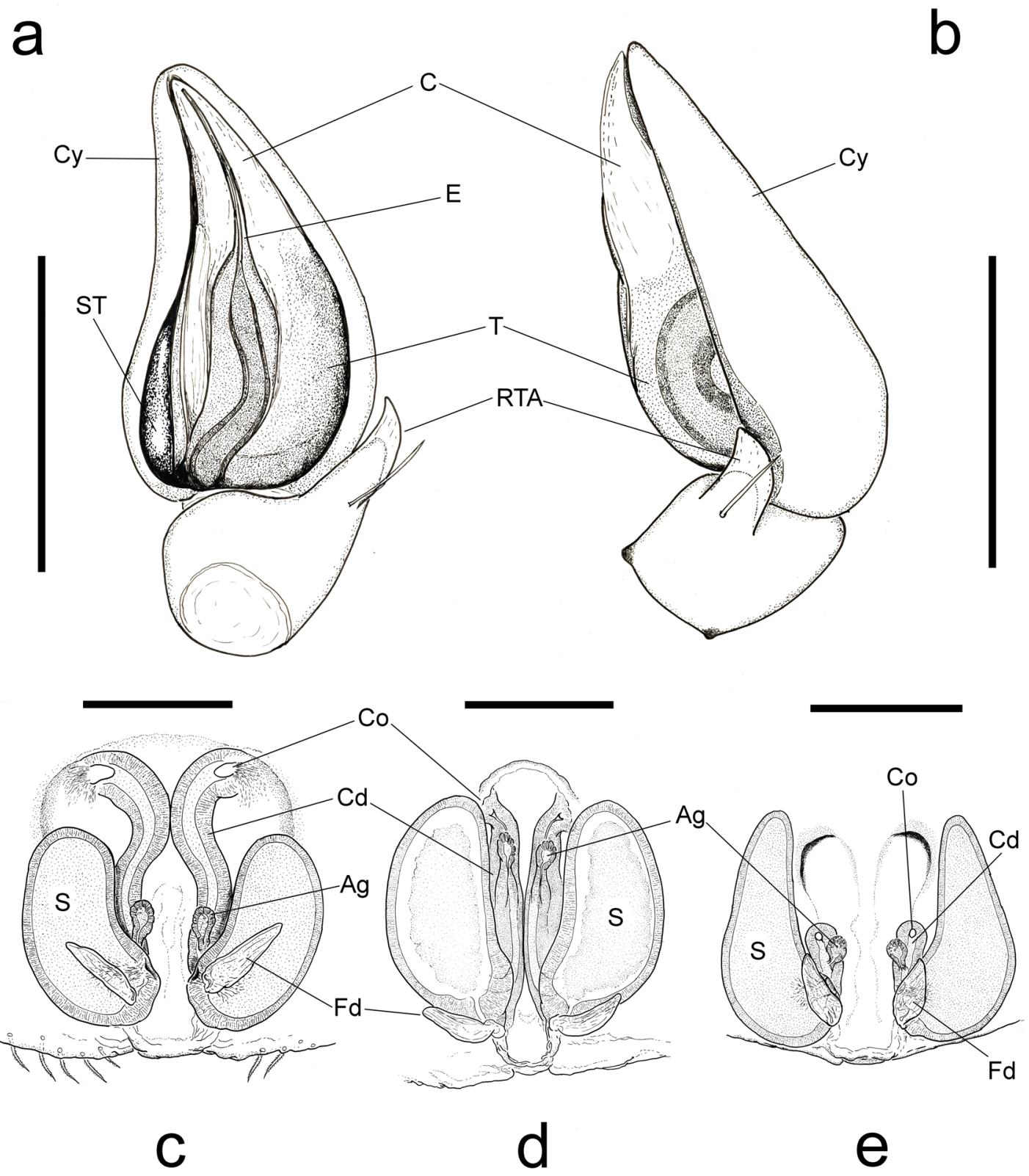

Fig. 3. Latonigena spp. genitalia. 1a-c L. pampa, sp. nov., a-b male holotype, left palp, c female paratype (MACN-Ar 18284); d L. pittieri sp. nov., female holotype; e L. santana Ott, Rodrigues \& Brescovit, female from Tandil (MACNAr 195); a ventral view, b retrolateral view; c-e cleared vulva, dorsal view. Scale bars: $\mathbf{a}-\mathbf{b} 0.5 \mathrm{~mm}, \mathbf{c}-\mathbf{e} 0.2 \mathrm{~mm}$. $\mathrm{Ag}=$ accesory glands, $\mathrm{C}=$ conductor, $\mathrm{Cd}=$ copulatory duct, $\mathrm{Co}=$ copulatory opening, $\mathrm{Cy}=$ cymbium, $\mathrm{E}=\mathrm{embolus}, \mathrm{Fd}=$ fertilization duct, $\mathrm{RTA}=$ retrolateral tibial apophysis, $\mathrm{S}=$ spermatheca, $\mathrm{ST}=$ subtegulum, $\mathrm{T}=$ tegulum.

ous, probably faded, the median one interrupted medially, the third subterminal (Fig. 2c); ventrally marbled brown except a wide whitish postepigastric area (Fig. 2f). Total length 3.40. Carapace 2.50 long, 1.50 wide. Eye diameters and interdistances: AME 0.066, ALE 0.087, PME 0.089, PLE 0.075; AME-AME 0.053, AME-ALE 0.016, PME-PME
0.12, PME-PLE 0.08, ALE-PLE 0.15. Leg measurements (legs I missing): II - femur 1.20/ patella 0.74 / tibia $0.81 /$ metatarsus $0.67 /$ tarsus 0.48 / total 3.90; III - 1.10/ 0.60/ 0.63/ 0.66/ 0.53/ 3.52; IV $-1.40 / 0.79 / 0.98 / 1.10 / 0.53 / 4.80$. Leg spination: (Leg I missing); II: Femora D 1-0-1-1; DP 0-0-1-1/ Tibiae P 0-0-1; V 1-2-0-2 ap/ Metatarsi 


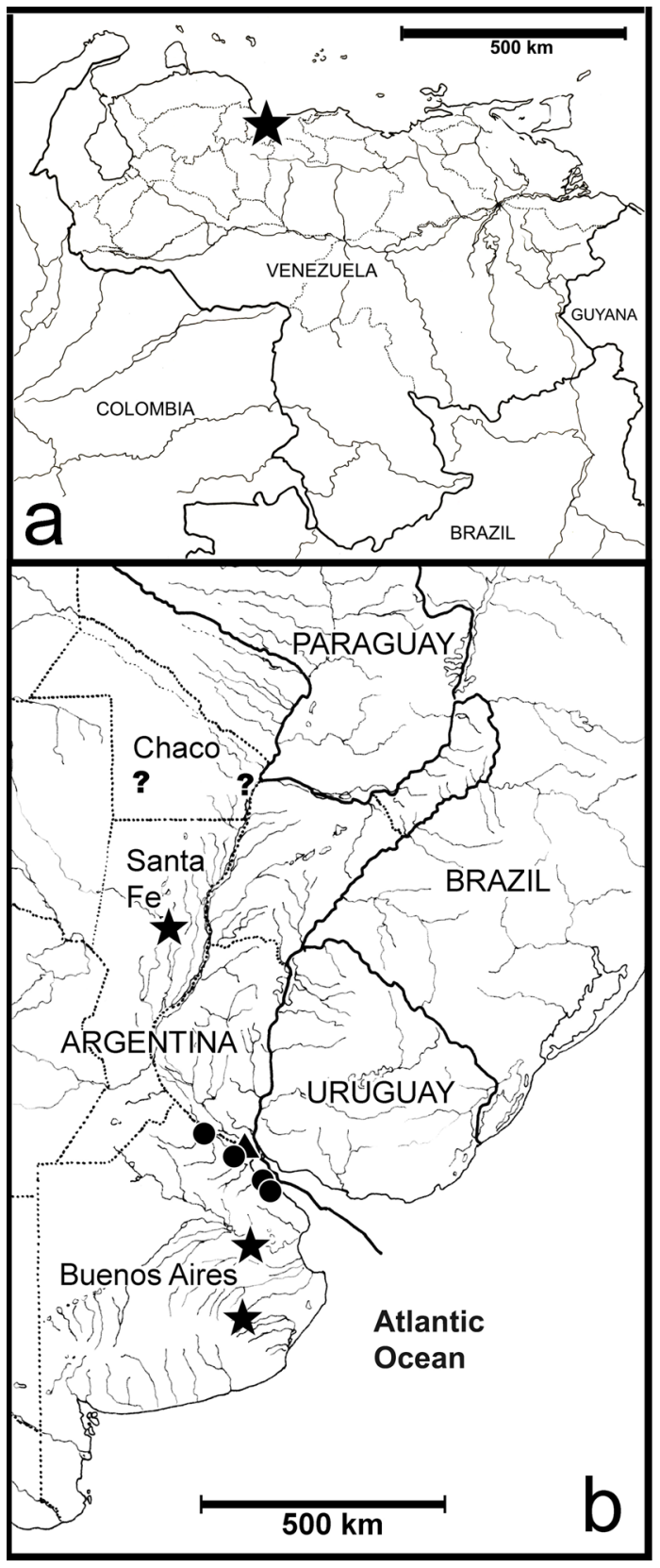

Fig. 4. Distribution maps of Latonigena species examined in the present study. a $L$. pittieri, sp. nov. (star); b $L$. pampa, sp. nov. (triangle), L. lami Ott, Rodrigues \& Brescovit (circles), L. santana Ott, Rodrigues \& Brescovit (stars), and L. turvo Ott, Rodrigues \& Brescovit (question marks indicate the localities of Charata (west) and Resistencia (east), both mentioned in the label, see text).

V 2-0-0. III: Femora D 1-0-1-1; DP 0-0-1-1; DR 0-0-1-1/ Patellae R 1/ Tibiae D 1-0-0; P 1-1; V 2; R 0-0-1; DR 1-0; VR 1 ap; VP 1-0-1 ap, DP 1-1-0-0/
Metatarsi DR 0-1-0-1; $\mathrm{R}$ 0-0-1; V 2-0-0-2; P 0-1$0-1$; DP 0-1-0-1. IV: Femora D 1-0-1-1; DR 0-0-0-1; DP 0-0-0-1/ Tibiae DR 1-0;R 0-0-1; P 1-0-1; VR 0-1-1; VP 1-1-1/ Metatarsi DR 1-1-1; DP 0-1-1; P 0-0-0-1; R 0-1-0-1; VP 1-1-1; VR 1-1-1. Genitalia: median septum anteriorly widened towards the anterior hoods, which are not touching medially (Fig. 2i). Spermathecae elongated, tapering anteriorly, copulatory ducts short, copulatory openings at the middle of the septum margin (Fig. 3e).

Distribution. Previously known only from the type locality, in Rio Grande do Sul (Brazil), its range is extended to Santa Fe and Buenos Aires provinces, in east central Argentina (Fig. 4b).

Latonigena turvo Ott, Rodrigues \& Brescovit (Fig. 4b)

Ott, Rodrigues \& Brescovit 2012:236. Holotype male from Parque Estadual do Turvo, Derrubadas, Rio Grande do Sul, Brazil, 4-8.V.2004, R. Ott et al. col., deposited in MCN. Not examined.

Material examined. Argentina: Chaco: "Resistencia y Charata" (sic), 06-VII-1934, J.B. Daguerre coll., 1 female (MACN-ar 18312). Note: The label is probably incorrectly transcribed, because Charata and Resistencia are two distant localities separated by more than $200 \mathrm{~km}$ (Fig. 4b).

Distribution. Previously known from Tocantins, Santa Catarina, and Rio Grande do Sul (Brazil), its range is extended to Chaco Province, in northeastern Argentina.

Latonigena lami Ott, Rodrigues \& Brescovit (Fig. 4b)

Ott, Rodrigues \& Brescovit 2012:230. Holotype male from Fazenda Guará, Tapes, Rio Grande do Sul, Brazil, 19.XII.2003, Equipe Probio col., deposited in MCN. Not examined.

Material examined. Argentina: Buenos Aires: San Pedro, S3335' W59²9', 18-VII-2009, N. López Carrión and N. Olejnik coll., 1 female. (MACN-Ar 30836); Zelaya, VII-1941, H. Hepper coll., 1 female (MACN-Ar 1032); Quilmes, no date, J. M. Viana coll., 1 female (MACN-Ar 25343). Ciudad Autónoma de Buenos Aires: Reserva Ecológica Costanera Sur (RECS), 09.XI.2011, in cabins, L. Zapata coll., 1 female. (MACN-Ar 30838), same reserve, S34욱' $1,75^{\prime \prime}$ W58ㅇำ50,28”, 04.XI.2011, C. Grismado and L. Zapata coll., 1 male (MACN-Ar 30837). 
Distribution. Previously known only from Paraná and Rio Grande do Sul (Brazil), its range is extended to Northeastern Buenos Aires province and Buenos Aires city, in east central Argentina (Fig. 4b).

\section{CONCLUSIONS}

The two new species here described are assigned to the South American genus Latonigena, previously known by only eight species. In addition, we record three species for the first time for Argentina (L. lami, L. turvo, and L. santana), previously known from Brazil. These new species and records allow us to extend the known range of the genus Latonigena from northern Venezuela to central Argentina. Because the material on which the current knowledge on this genus is based is scarce, it is expected that future collection efforts will allow a better understanding of the diversity and distribution of this group of spiders in the region.

\section{ACKNOWLEDGMENTS}

We thank to the authorities of the Administración de Parques Nacionales (APN) and the Reserva Ecológica Costanera Sur by the permits for collecting; to our co-collectors for their assistance in the field work. To Vladimir Ovtsharenko (American Museum of Natural History, New York) by his kindly return of specimens that he had under study. To Martín J. Ramírez, Carolina Jorge, and one anonymous referee, by useful comments on the draft.

\section{BIBLIOGRAPHY}

Grismado, C.J. 2008. A taxonomic revision of the spider genus Ariadna Audouin, 1826 in Argentina and Chile, with the description of five new species (Arachnida, Araneae, Segestriidae). Zoosystema 30: 333-360.

Holmberg, E.L. 1876. Arácnidos argentinos. Ann. agr. Rep. Argentina 4: 1-30.

Jorge, C., N. López Carrión, C.J. Grismado \& M. Simó. 2013. On the taxonomy of Latonigena auricomis (Araneae, Gnaphosidae), with notes of geographical distribution and natural history. Iheringia, Sér. Zool. 103: 66-71

Murphy, J. 2007. Gnaphosid genera of the world. British Arachnological Society, St Neots, Cambs, 1:i-xii, 1-92; 2:i-11, 93-605.

Ott, R., E.N.L. Rodrigues \& A.D. Brescovit. 2012. Seven new species of Latonigena (Araneae, Gnaphosidae) from South America. Iheringia, Sér. Zool. 102: $227-$ 238.

Platnick, N.I. 2013. The world spider catalog, version 14.0. American Museum of Natural History, online at http://research.amnh.org/entomology/spiders/ catalog/index.html DOI: 10.5531/db.iz.0001. 